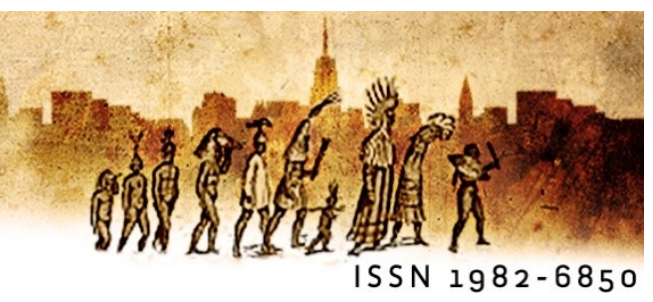

\title{
Escutas partilhadas: a coroação de reis Congo e "O recado do morro," de João Guimarães Rosa
}

\section{Shared listening: the coronation of the kings Congo and João Guimarães Rosa's "O recado do morro"}

\author{
Sérgio Bairon' (ECA-USP) \\ Marília Librandii (Princeton University)
}

\begin{abstract}
Resumo: Este ensaio explora o princípio de aproximação entre literatura e culturas de tradição oral ao estabelecer uma analogia entre o ritual da Coroação de Reis Congo, em Minas Gerais, e a noção de "escrita de ouvido" na novela de João Guimarães Rosa "O recado do morro" (1956). A análise combina a experiência de seis anos de pesquisa de campo com os grupos de Congada nas localidades de Jequitibá, Cordisburgo, Calabouço, Lagoa Trindade, Perobas, Onça e Brejinho, com a teoria da escuta na escrita praticada pelo autor mineiro.

Palavras-chave: Congada; escuta; escritas de ouvido; Sertão.
\end{abstract}

\begin{abstract}
This article explores the principle of approximation between literature and cultures of oral tradition by establishing an analogy between the ritual of the Coronation of Kings Congo, in Minas Gerais, and the notion of "writing by ear" in João Guimarães Rosa's novel "O recado do morro" (1956). The analysis combines the experience of six years of field research with the Congada's groups in the localities of Jequitibá, Cordisburgo, Calabouço, Lagoa Trindade, Perobas, Onça and Brejinho, with the theory of listening in writing practiced by the author from Minas Gerais.
\end{abstract}

Keywords: Congada; listening; writing by ear; Sertão.

Alguém também algo ouvira? Nada, não. J. G. Rosa, "O recado do morro"

Tudo tocando junto é igual a ouvir o silêncio. José Geraldo Alves

Zé da Ernestina, Rei Congo do Estado de Minas Gerais ${ }^{1}$

\footnotetext{
${ }^{1}$ Zé da Ernestina (José Geraldo Alves) foi Rei Congo do Estado de Minas Gerais entre os anos 1985 e 2010. Faleceu em 2012. Era um grande mestre de cultura oral da Coroação de Reis Congo, do Batuque de Viola, da
} 
As significações do universo oral no ritual da Coroação de Reis Congo no Estado de Minas Gerais relacionam um conjunto de ritos que expressam um complexo cotidiano de corporeidades faladoras fundamentadas em uma escuta coletiva. ${ }^{2}$ As expressividades dessa cultura oral sustentam concepções de um corpo individual-coletivo que se comunica pela composição e execução de um enorme acervo histórico e literário que denominamos aqui de cantorias, e que propomos reler em parceria com a teoria da escuta e da noção de "conconversa" na obra de João Guimarães Rosa (LIBRANDI 2015, 2016). O uso das cantorias na vida cotidiana reúne, em um só princípio, o corpo individual e o social, ou seja, o todo comunitário identifica-se e reproduz-se por meio da socialização da diversidade do uso das vozes locais que, a rigor, fundam-se e baseiam-se na receptividade da escuta. Em outras palavras, é no acontecimento da Coroação de Reis Congo que, no âmbito da escuta, é construído um universo discursivo-familietal, expressando um máximo de ressignificações históricas, sociais, religiosas e performáticas.

Esse processo de valorização da escuta como construção de saberes pode ser considerado utópico já que remete a uma versão superlativa da vida, cujo ponto em comum está na superabundância das cantorias, vivenciadas nos momentos de partilha da alimentação, na bebida em excesso, e na presença de nobrezas da simplicidade. As corporeidades adquirem uma condição sócio-individual sobretudo por valorizarem a heterogeneidade de saberes em cantorias, em uma expressividade de significações, que remetem sempre à superabundância, tendo por referência a vida cotidiana nas regiões do sertão. Tais características fazem desses rituais um momento de extremo regozijo, extrapolando qualquer noção homogênea de mundo. Desde já, é importante destacar que, tal como no processo de escuta, a identidade ocorre pela diferença, ou seja, pela incorporação de vozes e versões sempre outras, e em processo constante de variação e mudança.

Tendo por base o cotidiano da população que compõe estes rituais, são justamente os abundantes produtos consumidos na Coroação de Reis Congo (carne, pão, frutas e bebidas)

\footnotetext{
Folia de Reis, da Incelênça de Chuva, de Encomendação das Almas, da Festa do Divino etc. O presente depoimento ocorreu no contexto da pesquisa Cultura Afro-atlântica: Coroação de Reis Congo (2005-2011), coordenada por Sérgio Bairon e José da Silva Ribeiro. Agosto de 2008. Acervo pessoal, Sérgio Bairon.

${ }^{2}$ Sobre o contexto e significações histórico-antropológicas da Coroação de Reis Congo, ver ANDRADE, 1982, BORGES, 2005; LUCAS, 2002, e MELLO E SOUZA, 2002.
} 
que reforçam a expressividade da aproximação do trabalho da gente com a terra, adquirindo a forma desse realismo superlativo, não somente pela vitória frente à escassez, mas também pela necessidade de expressar compreensões de mundo por meio de um princípio musical na poeticidade das formas narrativas. Há uma espécie de consciência coletiva de que, assim como a terra, a árvore, os animais e as estações do ano, também o corpo socio-individual humano está em constante movimento de repetição e transformação. Esse entorno perpassa circularmente por uma incompletude material, que é movida pelos estágios do falecimento e do nascimento. Como diz Zé Meia-Noite, o coveiro da cidade de Jequitibá: tudo é que nem a festa: tem um começo e fim, pois o fim supremo estaria justamente nesse encontro que ocorre de forma concomitante entre a morte (de um sentido ou de um corpo) e o renascimento em cantorias.

As cantorias não colocam em contradição significados históricos passados e presentes, já que estes são sempre igualados; também não se trata simplesmente de inversão, mas de soma, positivação: Se Adão não pecasse não teríamos por que cantar, diz Zé da Ernestina, Rei Congo do Estado de Minas Gerais. ${ }^{3}$

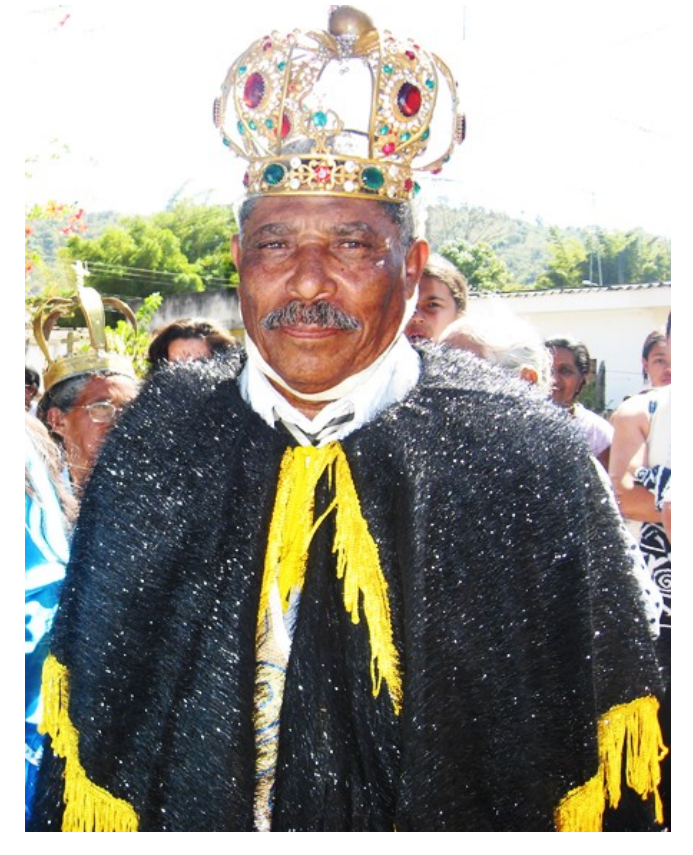

Zé da Ernestina (José Geraldo Alves)

Rei Congo do Estado de Minas Gerais

As cantorias comemoram e atualizam a libertação dos escravos, no sentido também de realçar um motivo para cantar a ação libertadora do próprio corpo:

\footnotetext{
${ }^{3}$ Depoimento gravado. Agosto de 2008. Acervo pessoal, Sérgio Bairon.
} 
Foi só sofrimento, só sofrimento. A minha mãe trabalhou na fazenda de escravos. Via coisa que ela contava, coisa triste que ela contava. E eu acredito mais fácil ser mil verdades que uma mentira. (ZÉ DA ERNESTINA, depoimento, dezembro de 2009)

E eu acredito mais fácil ser mil verdades que uma mentira. A representação do superlativo é aí, essencialmente, significação partilhada. O ritual de Coroação de Reis Congo é também o momento de afirmação e de ruptura do cotidiano. O caráter de ruptura que marca o acontecimento da Coroação, talvez esteja mais caracterizado no fato de inaugurar uma outra linguagem. Nela, o superlativo não está somente na vitória sobre a pobreza, mas também na vitória frente ao passado da escravidão, e no inefável universo de escutas que as cantorias produzem:

Lá, cê via alma penada, cê via, até hoje, cê vai pescá num córrego muito bonito que tem lá, ocê vê choro, ocê vê ranjura de dente, ocê vê gemido, lá nos fundo da fazenda, tanto que ninguém pesca lá. Foi muito sofrido.

(ZÉ DA ERNESTINA, depoimento, outubro de 2006)

\section{A Audição dos Recados}

Considerando o sertão como um lugar de ressonâncias, definimos a literatura de João Guimarães Rosa como uma "escrita de ouvido," ao mesmo tempo hiper-letrada e baseada no não-letramento, ou seja, na competência das práticas ágrafas. Nessas práticas, escritores como Rosa encontram o recado que a sua escrita literária ouve para re-transmitir. Nos estudos sobre a canção no Brasil, e sua importância como registro e como recado que se transmite, são exemplares os estudos de Luiz Tatit (2004) e de José Miguel Wisnik (1998). Como diz Tatit, para um vasto setor da população brasileira, que desenvolve práticas ágrafas, a canção chega como se fosse apenas outro modo de dizer casos do cotidiano; um outro modo de falar, assim como o canto atua como um prolongamento (acelerado ou desacelerado) da fala (2004, p.70). Como a entoação da fala é captada na escrita e na leitura? Essa é uma das perguntas a que o termo "escritas de ouvido" tenta responder.

A escrita literária reproduz a entoação da fala pelo uso de procedimentos poéticos incorporados na prosa (recursos fônicos, aliterações, assonâncias etc.); e também pela oralidade transcrita, ou seja, por uma escrita que segue os movimentos do falar. Se pensarmos em uma arte de receber os recados, ouvir o recado é, então, ouvir aquilo que escapa na mensagem recebida, por exemplo, a sua entoação: "a entoacão da fala tende a 
desaparecer assim que a mensagem do texto é transmitida" (TATIT, 2004, p.71). É assim que o escritor mineiro desenvolve ouvidos afinados para inscrever, no seu texto, a palavra cantada e a palavra falada, que são a matéria prima do seu local. "O recado do morro" é a síntese perfeita desse movimento: de ouvir a entonação, o recado da terra, do local, e configurá-lo em canção, em palavra cantada.

Diferente da mensagem, o termo "recado" remete a um segredo ou a um enigma que é preciso desvendar (cf. WISNIK, 1998). Em "O recado do morro," uma mensagem enigmática vinda de uma montanha (o morro da Garça) ecoa nos espaços abertos do sertão, e ressoa nos ouvidos de seis mensageiros, até que um trovador popular dá forma artística a esse recado. No final da viagem, uma canção é tocada, na véspera da festa da Coroacão de reis e rainhas negros, e a mensagem enigmática revela-se ao seu destinatário, Pedro Orósio, salvando a vida do herói, que termina em uma jornada planetária, quase divina, "saltando" de estrela a estrela." Nesse salto, o recado terreno (do morro da Garça, no sertão do Brasil) vira recado planetário e vira recado cosmológico e celestial.

Recado é um termo que significa "mensagem," "rumor" e "aviso," simultaneamente, e, na novela, remete a um tempo pré-babélico, quando a natureza fala. "Conconversa," termo que aparece na novela, é um neologismo que remete a um tempo pós-babélico, quando a multiplicidade de linguagens converge através da tradução, em busca de um sentido partilhado, apesar das diferenças linguísticas e culturais. Esses dois termos, "recado" e "conconversa," permitem pensar a prosa de ficção a partir de uma poética da escuta e dos efeitos da ressonância em uma literatura Luso-Afro-Ameríndia-Brasileira. A "conconversa" está baseada em diálogos orais, em um "texto falado" construído com muitas vozes em conversação, em uma convergência e divergência de muitas línguas em co-tradução, culminando em um silêncio ativo, quando a natureza fala sem palavras. A "conconversa," acentua, pois, a multiplicidades de vozes divergentes ecoantes nessa literatura: a fala das personagens, as conversas, a inter-tradução de uma língua préBabélica, a voz do morro, os sons da terra, os silêncios das estrelas, enfim, tudo que fala, em um "mundo escutado" (COSTA, 2005).

A relação entre o ouvir e o cantar, na Coroação de Reis Congo, é similar à relação entre o ouvir e a escrita, na obra de Rosa, pois o canto é sempre de ouvido, como dizia o Rei Congo do Estado de Minas Gerais. As cantorias constroem uma espécie de mundo de ressonâncias, ambientes que mesclam a corporeidade com as transveredas da região. Daí, 
tratar-se de uma ausculta palinódica da natureza. Ausculta porque imersa no sertão, palinódica porque se desdiz para dizer. Muitas vezes, as cantorias afirmam para negar, ou melhor, reconhecem o não sabido para que a terra possa se revelar enquanto "literatura não-letrada." A "conconversa" é também a matéria das cantorias. Cada discurso, cada objeto, cada imagem e cada edição da Coroação de Reis Congo institui, no seio da comunidade, uma forte sensação de homogeneidade calcada na diferença. Tal homogeneidade só é possível frente à diversidade das performances, e a "conconversa" está presente, justamente, na confusão dos sentidos em contraste. O contraste mais marcante nas cantorias é o do silêncio e da voz, pois a natureza não fala, ela canta, dizia Zé da Ernestina.

Nesses cotidianos, encontramos um enorme universo cultural cantado: cantam a medicina caseira, as coisas da fé, a alegria irônica da bebida, o mal funcionamento da técnica, a desconstrução da escola, as articulações corporais do artesanato, e tudo o mais que possa fazer sentido, a partir de um não dominar o tempo, pois são produções de vida que acontecem sem capitalizar. Assim, as cantorias não se movimentam no interior das contradições do mundo, mas se alimentam delas. A lembrança dos antepassados, a ornamentação da casa, a conservação da vida familiar, a vida artesanal-profissional, as ações sociais, a fala com o vizinho, com o prefeito, o namoro e o casamento, os rituais do enterro, as atividades comerciais, as brincadeiras das crianças, o julgamento da alteridade, o nome do vestuário, dos sapatos, as receitas da cozinha, as bebidas, a matança que resignifica os animais etc., tudo isso ocorre no interior da relação direta entre o ouvir e o cantar, que transcende cada povoado, cada cidade e cada região.

No interior dessas usinas de escutas literárias, o mundo acontece no presentepassado, porque as pessoas enxergam, na reverberação dos fatos, a maior razão para cantar. É esse espaço, concomitantemente, igualitário e diverso, que delega aos acontecimentos cotidianos um caráter de grande importância para a compreensão das próprias cantorias, considerando que elas são sempre criadas e recriadas a partir das vivências da audição de si próprias. Daí ficar há priscas eras de distância desse universo sonoro-auditivo, qualquer condição de autoria individual. Quando o ouvido se torna o centro das relações dialógicas é sempre o outro que se define como autoria. As cantorias podem, então, ser consideradas uma linguagem macro-sócio-cultural que fazem de todo artesão das auscultas o próprio instrumento da ressonância, dando condições para que 
todos participem, cada qual com sua habilidade.

A "conconversa" também habita o mundo dos instrumentos enquanto linguagem. Os processos de ressignificação não estão apenas nas cantorias, mas espalhados, inclusive, nas formas de reapropriação dos objetos, por exemplo, transformando um escapamento de carro em um "reco-reco," ou calotas de pneus em "chique-chique" ou, ainda, latas utilizadas como "gungas."

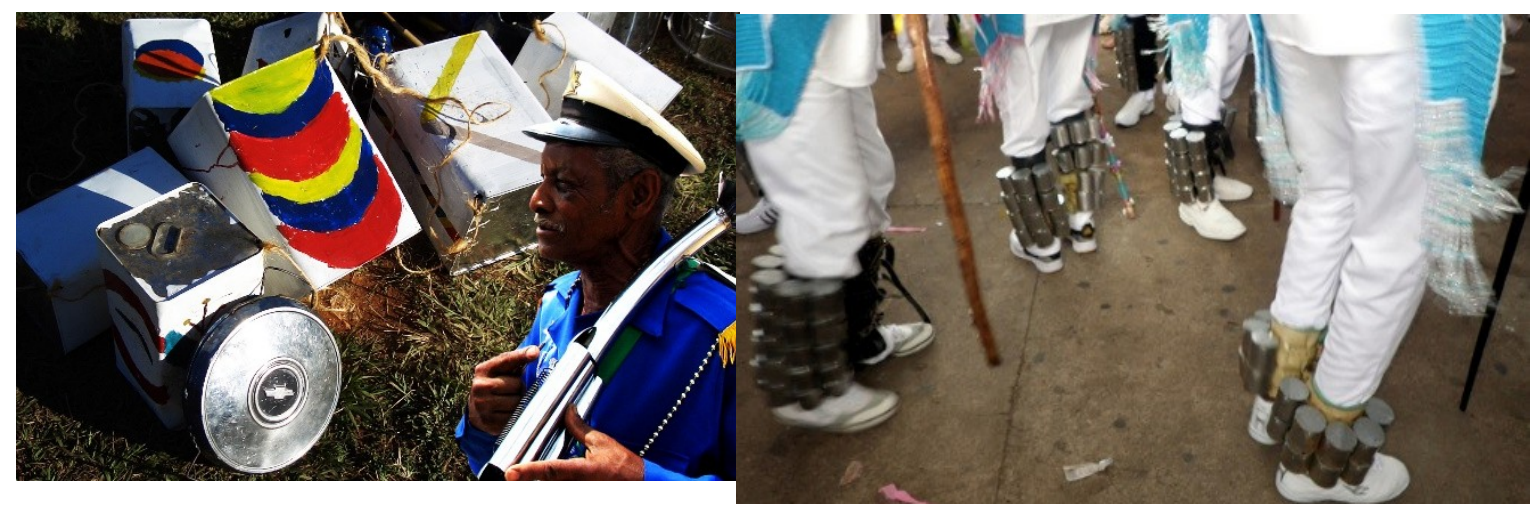

Instrumentos feitos de "sucatas" Montagem: Sérgio Bairon

Gungas utilizadas pelo grupos Moçambique

Nesse sentido, a preparação para o grande dia começa bem cedo. Arruma-se a casa, prepara-se a melhor roupa, tudo para o momento maior:

A festa era de pretos e brancos, mas mais dos pretos: já naquele dia eles espiavam os brancos com sobrançaria de importância maior - pois eram os donos da Santa. Carecia de mandar fazer um terno de brim novo, tirar do dinheiro para comprar umas duas ou três camisas, melhor das que têm bolsinhos. (ROSA, 1965, p.43)

Em "O recado do morro," temos uma narrativa de viagem composta por três jornadas interconectadas: a história de uma expedição ao longo do sertão; a história da viagem de um recado, desde o momento em que é pronunciado até sua decifração final como uma canção e, no terceiro nível, uma jornada planetária, pois a expedição passa por sete fazendas com nomes planetários, e o protagonista termina como um personagem mítico.

Tal como percebido por Guimarães Rosa, as cantorias na Coroação desdobram-se em uma escuta de três grandes percursos, que estão absolutamente interligados. primeiro percurso de cantorias está situado em grandes expedições pelo sertão, expedições que acompanhamos pelas localidades de Jequitibá, Cordisburgo, Calabouço, Lagoa 
Trindade, Peróbas, Onça e Brejinho. ${ }^{4} \mathrm{O}$ segundo percurso das cantorias está definido pela viagem de um recado, no caso da Coroação de Reis Congo, trata-se do recado do aparecimento da Santa (a imagem de Nossa Senhora do Rosário) na "praia do mar," e que deve ser divulgado por todos os grupos de congado em todos os recantos da terra. Nas narrativas sobre o mito de Nossa Senhora do Rosário, apresentadas por Lêda Martins, em seu livro Afrografias da Memória (1997), a constante menção às águas remete à questão da diáspora africana. Mas o mar tanto pode refletir a lembrança da viagem para o cativeiro quanto o vínculo com a terra de origem, apresentando uma conotação utópica como ponte de retorno ao continente africano (Couto, 1999). O terceiro percurso das cantorias implica uma jornada planetária que reúne historicidades da África, da Europa e do Brasil. A cultura oral da Coroação de Reis Congo é o resultado e a expressão do encontro entre culturas de Portugal, do Reino do Congo e do Brasil, que ocorreram desde o final do século XV. Esse encontro produziu uma cultura profundamente repleta de narrativas e cantorias.

No interior desse ritual, há uma grande valorização do processo de recontar as histórias relacionadas ao sertão brasileiro. Por um lado, cada grupo cultural conta de um jeito muito peculiar os mitos e histórias que envolvem a Coroação de Negros; de outro lado, no interior do mesmo grupo, costumam-se encontrar muitas variações das narrativas presentes no sertão. ${ }^{5}$

De modo similar, a literatura de Guimarães Rosa está repleta de cantorias e sobreposição de saberes, como é o caso de "O recado do morro." Assim como a literatura de Rosa, a cultura do sertão é reticular, na forma de uma rede de pontos (lugares) que estão em constante movimento. Os lugares são compostos por pessoas, acidentes geográficos, animais, ventos, passos, etc., que interligam as narrativas. Podemos chamá-los de "texturas sonoras" (Bairon, 2005): uma determinada sonoridade remete a um outra sonoridade, que remete a outra, e assim por diante, em um processo de mixagem e sobreposição sonora próprias tanto da sabedoria da cultura oral, como das características hipertextuais da obra de Guimarães Rosa.

\footnotetext{
${ }^{4}$ Regiões do Norte do Estado de Minas Gerais que englobam tanto uma forte e contemporânea presença da Coroação de Reis Congo, assim como o ambiente que contextualiza "O recado do morro," de Guimarães Rosa.

5 "Nos textos das narrativas ágrafas dos congadeiros, a história do aparecimento e resgate da imagem da santa metamorfoseia em muitas versões que guardam, entre si, um núcleo convergente. Transmitidas oralmente, essas narrativas revelam modalidades de recriação do tema, com recorrências, supressões e acréscimos próprios dos processos de transmissão oral, vestindo-se sempre com as estórias, cores, matizes e timbres dos lugares e do contexto que as assimilam, recriam e reproduzem (MARTINS, 1997, p.45).
} 
Como dissemos, "O recado do morro" é a história de uma expedição, uma viagem que começa na cidade natal de Guimarães Rosa, Cordisburgo, passa pela gruta do Maquiné, e segue em direção ao norte, em direção ao começo dos "campos gerais." O guia da viagem é Pedro Orósio, herói do conto, para quem o "recado do morro" se anuncia. Orósio é um trabalhador rural, não sabe ler nem escrever, mas seu porte físico o faz assemelhar-se a um herói. Durante a viagem, a comitiva passa por sete fazendas (com nomes planetários), e encontra sete personagens, que são os transmissores do recado do morro. Esses mensageiros são descritos por Rosa como "marginais da razão." Os mensageiros vão retransmitindo e compondo o recado, até que um poeta popular, Laudelim Pulgapé, dá forma artística e dá ao recado a forma de uma canção, que ele canta na véspera da festa da Nossa Senhora do Rosário. Pedro Orósio é o destinatário do recado, mas ele apenas entende o recado da mensagem quando esta é transformada em cantiga pelo poeta e cantador. Rememorando os versos da cantiga, ele compreende que, na verdade, seu colega, Ivo, planeja assassiná-lo junto com outros colegas, motivados por inveja e ciúmes. Desvendando o recado, Pedro Orósio se salva.

$\mathrm{Na}$ Coroação de Reis, temos sete grupos que levam o recado da Santa adiante. Esses grupos denominam-se: Congo, Moçambique, Candombe, Catopê, Vilão, Marujos e o Rei e a Rainha:

Também muitos já revestidos, para figurar na festança do dia-seguinte. Os dos ranchos: os moçambiqueiros, de penacho e com balainhos e guizos prendidos nas pernas; grupos congos em cetim branco, e faixa, só faltando os mais adornos; e a rapaziada nova, com uniforme da guarda-marinheira. Imponente foi quando comungaram o preto Zabelino, todo sério, e a preta Maria-da-Fé, com um grande ramo de flores nos braços, quens iam ser reicongo e rainha-conga. (ROSA, 1965, p.38)

Justamente por destacar uma escuta da terra é que a Coroação de Reis Congo, assim como "O recado do morro," mistura os elementos geográficos para desconstruí-los: os lugares perdem a geografia, e Jerusalém fica perto do Congo; as temporalidades são cruzadas e Carlos Magno é coroado em 1500, ou em 1900, e não no ano 800, e os nomes próprios da história oficial são re-significados nessas temporalidades e espacialidades, como o fato de que Fernando Aragão encontrou sua esposa Isabel de Castella no Brasil. A questão é que os fatos históricos perdem sentido porque não é a verdade exposta nas interpretações de texto que interessam, mas a verdade que se revela pela diversidade de 
ouvidos escutando a própria historicidade do sertão: "E eu acredito mais fácil ser mil verdades que uma mentira" (ZÉ DA ERNESTINA).

\section{O Superlativo do Corpo, da Terra e da Ressonância}

Nessa cosmologia, recriada em Guimarães e também presente na Coroação de Reis Congo, o gozo e o sofrimento da felicidade, nas cantorias, advém do mais profundo caráter repetitivo de um sentido social interpretado "verbalmente" pelo ouvido e pelos atos da escuta. A escrita de Guimarães Rosa em "O recado do morro" em relação às cantorias adquire, então, um duplo de escuta: a escuta do autor a respeito da cosmologia presente no sertão da Coroação de Reis Congo, e a escuta dos seres que são capazes de ouvir ultra-sons. $\mathrm{Na}$ verdade, a obra de Guimarães Rosa parece aproximar-se fantasticamente dessa cosmologia da escuta, como se toda a comunicação fosse norteada pelo auricular e, de quando em quando, incidentalmente, como em um flash fotográfico, transforma-se em escrita. Aqui, há um sentido cosmológico que reforça o princípio de que, tal como no mundo das cantorias, o texto de Guimarães Rosa não foi desenvolvido prioritariamente para os olhos lerem, mas para os ouvidos escutarem aquele mundo.

O encontro das guardas que acontece na Coroação de Reis Congo é um dos momentos em que estas características das escutas são vividas ao extremo. Muitas vezes, três, cinco ou mais guardas (cada qual com uma média de vinte integrantes) realizam, ao mesmo tempo, músicas e performances diferentes, ou seja, cada guarda e todas juntas, concomitantemente, tocando os instrumentos e bravejando as cantorias. Tudo tocando junto é igual a ouvir o silêncio, dizia o Rei Congo do Estado de Minas Gerais. Poderíamos dizer que, tudo tocando junto é similar ao "silêncio sonoro" da leitura definida pela escuta, pois a palavra ouvida, no silêncio da leitura, possibilita a ausculta de um mundo, que mistura a linguagem coletiva da terra e das gentes, assim como o passado, presente e futuro.

Como traduzir esse mundo? Como traduzir Guimarães Rosa se o que se expressa em sua obra inclui a presença do universo da letra não letrada? Essas questões fazem-nos refletir sobre o fato de que a sua linguagem escrita resulta das condições de escuta, tais como as que identificamos na transmissão e criação das cantorias. 


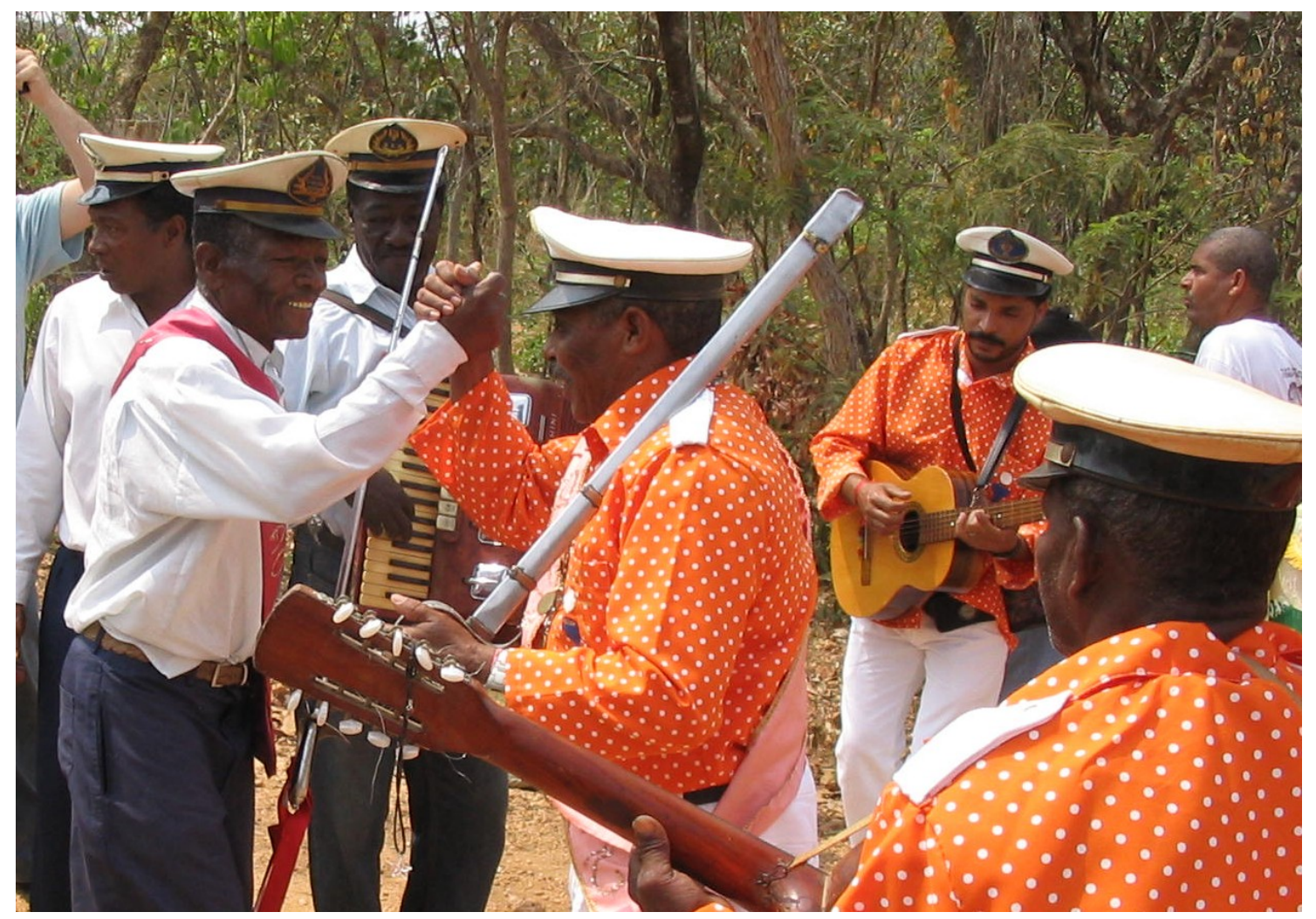

Encontro das Guardas do congo de Zé da Ernestina e dos Bianos -

Brejinho - Jequitibá - Minas Gerais - setembro - 2007 - Foto: Sérgio Bairon

Nesse contexto, é interessante trazermos as noções de paisagem sonora e de ouvido pensante, propostas pelo canadense Murray Schafer (1998). De certa maneira, poderíamos afirmar que Shafer teorizou para área da música, o que as cantorias e a literatura de Guimarães Rosa já haviam anunciado: a paisagem sonora é uma expressão dos elementos constituintes da sonoplastia do universo, o som, o silêncio, o ruído, os timbres, as amplitudes, a melodia, a textura e o ritmo; já o conceito de ouvido pensante pressupõe que, ao contrário dos outros sentidos, os ouvidos estão sempre expostos e vulneráveis: "(...) os olhos podem ser fechados, se quisermos; os ouvidos não, estão sempre abertos" (SCHAFER, 1991, p. 67). 


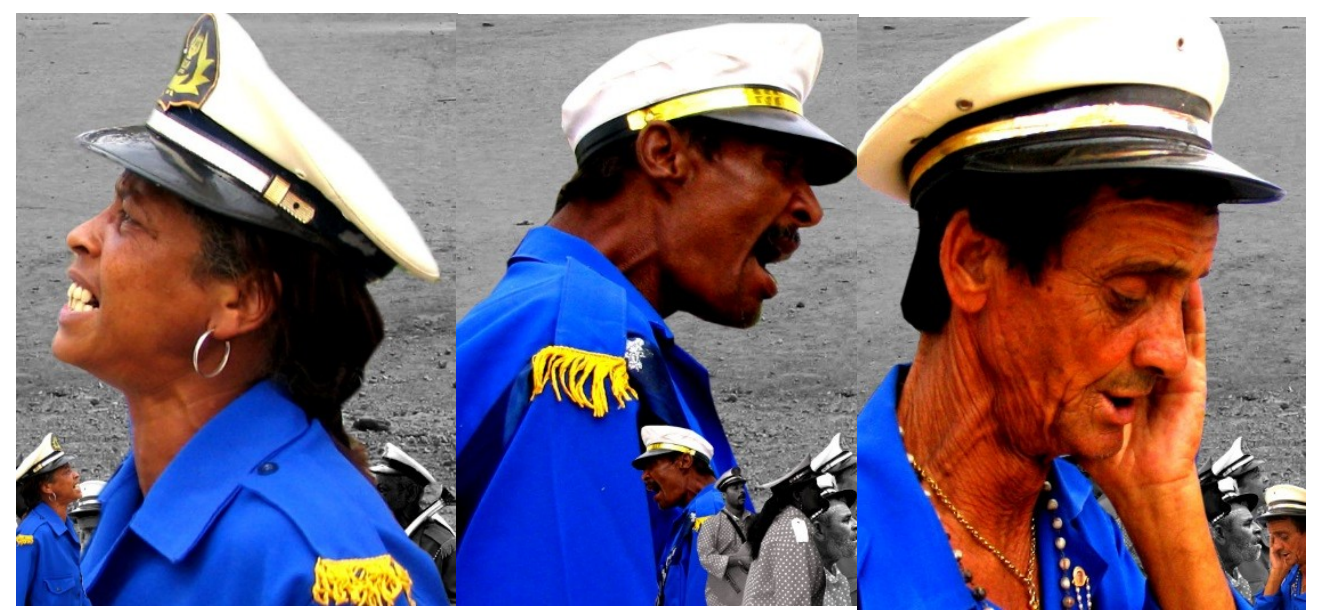

Cantorias - Guarda Capão de Sete Lagoas - MG - Montagem Sérgio Bairon

Talvez, seja esse o sentido mais profundo da abundância de escuta presente no universo da Coroação de Reis Congo: uma homenagem da escuta coletiva ao trabalho sonoro da coletividade em meio ao sertão. A ressonância dos sentidos, nessas paisagens sonoras, ocasiona um ecoar de sonoridades. Vejamos um caso do ressoar que é, na verdade, prioritariamente e finalmente escuta: o violeiro João da Silva afina sua viola pelo som do pássaro de nome "Peixe Frito." A viola afinada pelo pássaro serve de base para cantorias da Coroação de Reis que, por sua vez, são acompanhadas pelas vozes compostas em três ou quatro tonalidades. Não seria exagero afirmar que, nesse caso, graças à preponderância do ouvido, é o pássaro que está cantando nas cantorias da Coroação de Reis Congo. Na multiplicidade deste ressoar, encontra-se o fundamento mítico do encontro entre humanos e natureza, e que nega a esta um valor simplesmente contemplativo.

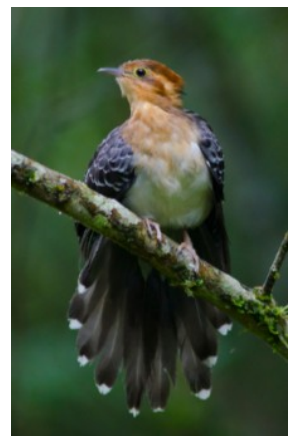

Peixe frito Fonte: Wikiaves

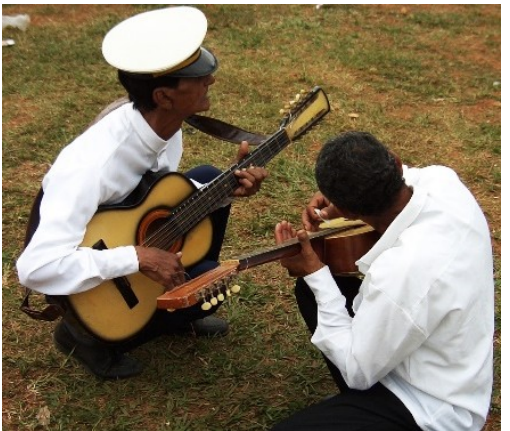

Violeiros Guarda Bianos Foto: Sérgio Bairon

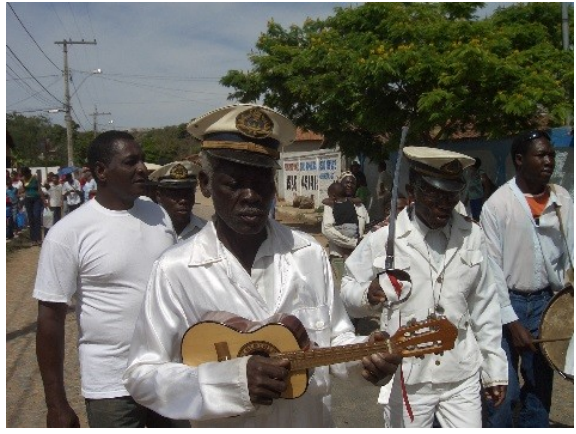

Bianos tocando na Guarda Foto: Sérgio Bairon

As narrativas míticas expressas na ontologia das cantorias delegam uma tópica cultural 
continuamente identificada com a diversidade das regionalidades em questão. É justamente essa diversidade que provoca grandes mudanças de conteúdo, das narrativas às performances. Há, portanto, um processo de contínua regeneração cultural. Nesse sentido, não se trata do desencontro do cotidiano com o superlativo da Coroação de Reis, mas da transformação do cotidiano numa ressignificação superlativa do sertão.

Nesse contexto, as cantorias também transformam a religiosidade em uma temática para que o mundo da "conconversa" se manifeste, de modo similar ao aparecimento do boiadeiro, ex-matador de jagunços, que se apaixonou por uma prostituta no conto "Dão Lalalão," de Guimarães Rosa. Dão Lalalão é uma expressão sonora do badalar do sino, que desconstrói os cantos bíblicos. Assim também o sino em "O recado do morro." Ouçamos o texto de Rosa:

E de repente o sino do Rosário se tangeu - col a col, cantarol. Ah, quem batia, sabia: tantoava em repique e repinico, muito claro no bimbalho. Mas, foi logo a forte, dez mãos pelo badalo, pegou a bedelengar a torto, dlá e dlém, parecia querer romper de vez a forma de seu caroço dele. Virgem! - Nominedômine tinha alcançado de chegar à torre, a igreja estava entregue aos máscaras, carecia de o pessoal todo do arraial correr para lá. O homem dava rebate, rebimbo, dobra que redobrava, a tal. Depois, perdia qualquer estilo. Era só aquela fúria: dladlava, dlandoava, o sino também fervia do juízo! Ora, o sinão do Rosário é reinol, de boa marca, bem santificado: é sino de uma légua. A portanto, aquilo bronze zoava fora de rol, transtornava a gente. Agora, sim, o Nominedômine, Nomendome, Santos-Óleos ou Jubileu - ele cujo tinha encontrado seu poder de rachar os ouvidos do povo todo, em prol, com sua gritação do fim do mundo. (ROSA, 1965, p.36)

As festividades da Coroação de Reis Congo sempre estiveram lidando com a diversidade absoluta: a proibição da Igreja, a presença de "doidos" e "desajustados," as narrativas que desconstroem a geografia física, a eleição e escolha de meninos-reis, e a diversidade de violeiros e cantorias, que iam se adaptando e se transformando a cada período e lugar da festa:

Falar nisso, o sino repicou, era hora da reza, noveneira. Outra vez o povo para a igreja. (...) Enfileirada no adro, a turma dos Moçambiqueiros, completa, à luz da tarde. Da outra banda, a Guarda Marinheira, dava prazer ver o estique deles, cada um de queixo alto - nenhum não se ria. E já vinham chegando os Congos, a toque de rufo, pessoal do Tú e do Mascamole adiante. Aqueles ranchos todos porfiavam. E passavam muitas senhoras, levando para dentro suas crianças em branco, preparadas de virgens e de anjos. Só mesmo na hora em que os coroinhas do padre tangeram sineta, foi que esbarrou, a um tempo, de cá e de lá, o tungo e o 
vungo das caixas de couro. Ah, uma festa, com suas saúdes, era boa estância, mesmo assim de véspera só. (ROSA, 1965, p.44)

Sendo o princípio básico tanto das cantorias quanto da literatura roseana, a festa cria uma imagem de futuro farto e abundante de escutas, proporciona uma vivência ontológica e paradoxal para a experiência do cotidiano, e uma cosmologia positiva para o futuro. Tal como no desfecho de "O recado do morro," esta cosmologia positiva pode ser a morte como a salvação... Até porque, quando chegamos ao fim, mesmo a dualidade mortesalvação perde sentido:

Eu dou graças a deus, se eu pudesse ir lá aonde ele está:

Vovô era de Congo

Morador do lado de lá

eu também sou filho de congo

eu também quero ir pra lá

É pra onde a gente vai mesmo..., né? (risos) (ZÉ DA ERNESTINA)

Ou na versão roseana:

(...) afundar naquele bafo sem tempo, sussurro sem som, onde a gente se lembra do que nunca soube, e acorda de novo num sonho, sem perigo sem mal; se sente. (ROSA, 1965, p.44)

\section{Bibliografia Citada}

ANDRADE, Mario de. Danças dramáticas do Brasil. Edição organizada por Oneyda Alvarenga. 2.ed. Belo Horizonte: Itatiaia; Brasília: INL/Fundação Nacional Pró-Memória, 1982.

BAIRON, Sérgio. Texturas sonoras. São Paulo: Hacker, 2005.

BASTIDE, Roger. As religiões africanas no Brasil: contribuição a uma sociologia das interpretações de civilizações. 2.ed. São Paulo: Pioneira, 1985.

BORGES, Célia Maia. Escravos e libertos nas Irmandades do Rosário: devoção e solidariedade em Minas Gerais - séculos XVIII e XIX. Juiz de Fora: UFJF, 2005.

COSTA, Ana Luiza Martins. "Mundo escutado." Revista Scripta 9.17, pp. 47-60, 2005. 
COUTO, Patrícia Brandão. Festa do Rosário. Iconografia e Poética de um Rito. Rio de Janeiro: Ed. EdUFF, 1999.

LIBRANDI, Marília. "Escritas de ouvido na literatura brasileira." Literatura e Sociedade. Universidade de São Paulo. n. 19, 2015, p. 131-148.

LIBRANDI, Marília. "Multiple Rumors: Recado and Conconversa in João Guimarães Rosa's fiction." Luso-Brazilian Review. Vol. 53, n. 2, 2016, pp.62-83.

LUCAS, Glaura. Os sons do Rosário: o congado mineiro dos Arturos e Jatobá. Belo Horizonte: UFMG, 2002.

MARTINS, Leda. Afrografias da Memória. Campinas: Ed. Unicamp, 1997.

MELLO E SOUZA, Marina de. Reis negros no Brasil escravista. História da festa de coroação de Rei Congo. Belo Horizonte: Editora da Universidade de Minas Gerais, 2002.

ROSA, João Guimarães. "O recado do morro." No Urubuquaquá, no Pinhém (Corpo de Baile). $3^{\text {rd }}$ ed. Rio de Janeiro: Livraria José Olympio Editora, 1965.

SCHAFER, Murray. O Ouvido pensante. São Paulo: Ed. UNESP, 1998.

TATIT, Luiz. O século da canção. Cotia: Ateliê Editorial, 2004.

WISNIK, José Miguel. "Recado da viagem." Scripta, 2. 3. Belo Horizonte: PUC/MG. (1998) 160-170.

\footnotetext{
'Professor na Escola de Comunicação e Artes- Núcleo Diversitas-USP.

E-mail: sbairon@usp.br

ii Leitora, Department of Spanish and Portuguese, Princeton University.

E-mail: marilialibrandi@gmail.com
} 